\title{
Association between vegetable consumption and calf venous compliance in healthy young adults
}

\author{
Anna Oue ${ }^{1 *} \mathbb{D}$, Yasuhiro limura ${ }^{2}$, Kotose Maeda $^{2}$ and Takahiro Yoshizaki ${ }^{1}$
}

\begin{abstract}
Background: Venous compliance decreases with aging and/or physical inactivity, which is thought to be involved partly in the pathogenesis of cardiovascular disease such as hypertension. This suggests that it is important to maintain high venous compliance from a young age in order to prevent cardiovascular disease. Both nutrient and exercise could play an important role in the improvement and maintenance of vascular health. Indeed, habitual endurance exercise is known to improve the venous compliance, although little is known about the effect of diet on venous compliance. Considering that higher consumption of vegetables could contribute to the arterial vascular health and the decreased blood pressure, it is hypothesized that venous compliance may be greater as vegetable intake is higher. Thus, the purpose of this study was to clarify the association between vegetable intake and venous compliance in healthy young adults.

Methods: Dietary intake was assessed in 94 subjects (male: $n=44$, female: $n=50$ ) using a self-administered diet history questionnaire (DHQ). Intakes of nutrients and food groups that were obtained from the DHQ were adjusted according to total energy intake using the residual method. Based on the adjusted intake of food groups, total vegetable intake was calculated as the sum of green/yellow and white vegetables consumed. Calf volume was measured using venous occlusion plethysmography with a cuff deflation protocol. Calf venous compliance was calculated as the numerical derivative of the cuff pressure-calf volume curve. In addition, circulatory responses (heart rate and systolic and diastolic blood pressure) at resting and maximal oxygen uptake were assessed in all subjects.
\end{abstract}

Results: Mean value of total vegetables intake was $162.2 \pm 98.2 \mathrm{~g} /$ day. Simple linear regression analysis showed that greater venous compliance was significantly associated with higher total vegetable consumption $(r=0.260, P=$ $0.011)$ and green/yellow vegetable intake $(r=0.351, P=0.001)$ but not white vegetable intake $(r=0.013, P=0.902)$. These significant associations did not change in the multivariate linear regression models which were adjusted by sex and maximal oxygen uptake.

Conclusion: These findings suggest that higher consumption of vegetables, especially of the green/yellow vegetables, may be associated with greater venous compliance in young healthy adults.

Keywords: Blood pressure, Green/yellow vegetables, Nitric oxide, Venous distensibility

\footnotetext{
* Correspondence: oue@toyo.jp

${ }^{1}$ Faculty of Food and Nutritional Sciences, Toyo University, 1-1-1 Izumino, Itakura-machi, Ora-gun, Gunma 374-0193, Japan

Full list of author information is available at the end of the article
}

(c) The Author(s). 2020 Open Access This article is licensed under a Creative Commons Attribution 4.0 International License, which permits use, sharing, adaptation, distribution and reproduction in any medium or format, as long as you give appropriate credit to the original author(s) and the source, provide a link to the Creative Commons licence, and indicate if changes were made. The images or other third party material in this article are included in the article's Creative Commons licence, unless indicated otherwise in a credit line to the material. If material is not included in the article's Creative Commons licence and your intended use is not permitted by statutory regulation or exceeds the permitted use, you will need to obtain permission directly from the copyright holder. To view a copy of this licence, visit http://creativecommons.org/licenses/by/4.0/. The Creative Commons Public Domain Dedication waiver (http://creativecommons.org/publicdomain/zero/1.0/) applies to the data made available in this article, unless otherwise stated in a credit line to the data. 


\section{Background}

Aging and physical inactivity cause the decrease in venous compliance as well as arterial compliance [1-4]. Veins are highly compliant vessels that contain $60-70 \%$ of total blood volume at rest. The changes in venous capacitance and/or venous compliance with physiological stresses cause the adequate transfer of blood from the vein to the heart, so that cardiac output and blood pressure maintains [5]. This suggests that attenuated venous compliance could have an adverse influence on cardiovascular health. Indeed, the decreased venous compliance has been observed in hypertensive humans [6, 7] and animals [8-10], and the elevation of venous vascular stiffness is thought to be involved partly in the pathogenesis of hypertension. Therefore, it is important to maintain high venous compliance from a young age in order to prevent cardiovascular disease.

Both nutrient and exercise could play an important role in the improvement and maintenance of vascular health. Indeed, habitual endurance exercise is known to increase venous compliance [1, 2, 11-13]. However, little is known about the effect of diet on venous compliance. High consumption of plant-based foods is associated with a reduced risk of cardiovascular disease [14-16]. In addition, the increased consumption of fruit and vegetables produced significant improvement in endothelium-dependent arterial vasodilation in hypertensive subjects [17]. These suggest that high consumption of vegetables could have a beneficial influence on arterial vascular health. Vegetables contain various nutrients, non-nutrients (e.g., fiber, vitamin $C$, vitamin $K$, magnesium, and potassium) and phytochemicals (e.g., flavonoids, carotenoids, nitrates, and organosulfur compounds), which have many physiological functions $[18,19]$. In particular, the antioxidant, the anti-inflammatory activity, and the increased nitric oxide (NO) synthesis are thought to be possible mechanisms for improvement of cardiovascular and arterial vascular health [20-23]. For example, green leafy vegetables contain many amounts of nitrate that can increase the NO level via the enterosalivary nitrate-nitrite-NO pathway [24]. Furthermore, it has been reported that the consumption of plant-derived bioactive nitrates improved the flowmediated arterial dilation [25-32] and the pulse wave velocity [29, 31-33]. Considering that NO activity could also contribute to the control of venous tone [34-38], higher consumption of vegetables, especially green/yellow vegetables, could be expected to affect venous compliance.

Thus, the purpose of this study was to investigate the association between vegetable consumption and venous compliance in young healthy adults. It is hypothesized that the consumption of vegetables, especially green/yellow vegetables but not white vegetables, would positively correlate to venous compliance.

\section{Methods}

\section{Subjects}

Ninety-eight young healthy subjects with no overt chronic disease volunteered to participate in this study. All subjects were nonsmokers and not taking any medications. In addition, subjects refrained from caffeine, alcohol, and exercise for $24 \mathrm{~h}$ and food intake for $2 \mathrm{~h}$ before each experiment. The study was approved by the Human Ethics Committee of Toyo University (approval no. TU2017-006) and was conducted in accordance with the Declaration of Helsinki except for registration in a database. All subjects provided written and verbal informed consent after receiving a detailed explanation of the purpose, procedures, and risks of the study.

\section{Study design}

Subjects visited the experimental laboratory on two occasions. At the first visit, they completed a selfadministered diet history questionnaire (DHQ) that assessed their intake of nutrients and food groups. Any mistakes or inconsistencies in responses to the questionnaire items were followed up by well-trained researchers. At the second visit, circulatory responses, venous vascular properties, and maximal oxygen uptake $\left(\dot{\mathrm{V} \mathrm{O}}_{2 \max }\right)$ were measured in this order.

\section{Measurements \\ Intake of nutrients and food groups}

Habitual dietary intake during the previous 1 month was assessed using the DHQ $[39,40]$. This questionnaire assesses eating behavior, the amount of 150 kinds of foods consumed, and the amount of 40 kinds of nutrients consumed per day. Data obtained from the DHQ for intake of nutrients and food groups were adjusted according to total energy intake using the residual method [41]. Based on the adjusted intake of food groups, total vegetable intake was calculated as the sum of green/yellow and white vegetables consumed. Energy intake derived from the DHQ has been reported to be moderately correlated with energy expenditure calculated using the doublelabeled water method (correlation coefficient: 0.42 for males and 0.37 for females) [42]. Moreover, energyadjusted vegetable intake determined from the DHQ has also been reported to be moderately correlated with semi-weighted dietary records (correlation coefficient: green and yellow vegetables, 0.32 for males, 0.47 for females; other vegetables, 0.43 and 0.48 , respectively) [39].

\section{Circulatory response}

Systolic (SBP) and diastolic (DBP) blood pressure and heart rate (HR) at rest were measured using an automated sphygmomanometer with the subject in the supine position (Tango M2 Stress Test Monitor, SunTech 
Medical Inc., Morrisville, NC). The double product (DP) was calculated as the product of SBP and HR.

\section{Vascular properties of the calf}

All subjects rested in the supine position for at least 20 min before data acquisition. To measure change in calf volume, a venous collecting cuff was wrapped around the left thigh and a mercury strain gage was placed on the site of maximal calf thickness. The collecting cuff was inflated to $60 \mathrm{mmHg}$ for $8 \mathrm{~min}$, after which the cuff pressure was manually reduced from 60 to $0 \mathrm{mmHg}$ at a rate of $1 \mathrm{mmHg} / \mathrm{s}$ according to a previously described cuff deflation protocol [43]. Calf volume during cuff inflation and deflation was measured noninvasively using a venous occlusion plethysmography (Hokanson, EC6, D. E. Hokanson, Bellevue, WA). A rapid increase in limb volume was evoked within 3-4 min of raising the cuff pressure to $60 \mathrm{mmHg}$, which represented the maximal blood volume stored in the veins, and was followed by a slower fairly linear volume increase caused by net filtration into the extravascular space. We calculated this filtration-dependent increase using the model developed by Skoog et al. [44] and corrected for the limb volume during inflation and deflation of cuff pressure.

Using the corrected calf volume curve, we assessed the vascular properties of the calf venous system as follows. The relationship between cuff pressure and change in calf volume (i.e., the pressure-volume curve) was generated from the data points between 10 and $60 \mathrm{mmHg}$ during the cuff deflation protocol. To avoid any a priori assumptions about the pressure $(\mathrm{P})$-calf volume $(\mathrm{V})$ curve and to obtain a physiologic venous compliance curve, venous compliance was calculated as the numerical derivative of each pair of pressure-calf volume data points using the following equation [12, 45].

$$
\text { Venous compliance } e_{P i}=\frac{\mathrm{V}_{i}-\mathrm{V}_{i-5}}{\mathrm{P}_{i}-\mathrm{P}_{i-5}} \text {, where } 15 \leq i \leq 60
$$

Venous compliance at $20 \mathrm{mmHg}$ of cuff pressure was used as the representative value $[2,43]$. Venous capacitance was evaluated as the change in limb volume from before the cuff inflation to $8 \mathrm{~min}$ of cuff inflation at 60 $\mathrm{mmHg}$. Venous outflow was calculated from the rate of change in limb volume for 1 min during cuff deflation from 60 to $0 \mathrm{mmHg}$.

\section{Maximal oxygen uptake}

Subjects were required to undertake an incremental cycling exercise test $(2-30 \mathrm{~W} / \mathrm{min}$, pedaling frequency 60 rpm) using a cycle ergometer (Aerobike 75XLШ, Konami Sports Life Co., Ltd., Kanagawa, Japan). Ventilatory and gas-exchange parameters were measured breath-by-breath using a computerized metabolic measuring system (Aero
Monitor 310S, Minato Medical Science, Osaka, Japan). HR was measured simultaneously using a monitor (Polar F11, Polar, Kempel, Finland) connected to the metabolic measuring system. At least two of the following criteria were used to determine $\dot{\mathrm{V}} \mathrm{O}_{2 \max }$ : a respiratory gas exchange ratio $>1.05$, HR within $10 \mathrm{bpm}$ of the agepredicted maximal HR, and inability to maintain a pedaling frequency of $50 \mathrm{rpm}$.

\section{Statistical analysis}

Four of 98 participants who were at the extremes of energy intake $(<500 \mathrm{kcal} /$ day or $>3500 \mathrm{kcal} /$ day for women; $<800 \mathrm{kcal} /$ day or $>4000 \mathrm{kcal} /$ day for men) were excluded from the study [46], leaving data for 94 subjects (44 male, 50 female; age 19-23 years) for inclusion in the analysis. Data are expressed as the mean \pm standard deviation for continuous variables and as the number (\%) for categorical variables. Spearman's rank correlation coefficients were calculated to examine the relationship between total vegetable intake and subject characteristics. For simple and multivariate linear regressions, venous compliance was used as the dependent variable, and total vegetable intake, green/yellow vegetable intake, and white vegetable intake were used as independent variables. For multivariate linear regression, an extended model with a covariate adjustment approach was used: model $1=$ intake of each vegetable group and sex; model $2=$ model 1 plus $\dot{\mathrm{V}}_{2 \text { max }}$. Statistical analysis was performed using the SPSS software version 19 (IBM Corp., Armonk, NY). A $P$ value of less than 0.05 was considered statistically significant.

\section{Results}

Mean value of total vegetable intake was $162.2 \pm 98.2 \mathrm{~g}$. In addition, venous compliance, venous capacitance, and venous return in the calf were $0.087 \pm 0.030 \mathrm{~mL} / 100 \mathrm{~g}$ tissue $/ \mathrm{mmHg}, \quad 2.93 \pm 0.88 \mathrm{~mL} / 100 \mathrm{~g}$ tissue, and $2.98 \pm$ $0.79 \mathrm{~mL} / 100 \mathrm{~g}$ tissue $/ \mathrm{min}$, respectively. Total vegetable intake was higher in female than male $(P<0.05)$, and had significant negative association with height, weight, SBP, and DP $(P<0.05$, Table 1$)$. Furthermore, total vegetable intake had a significant positive relationship with intake of protein, fat, potato, green/yellow vegetables, white vegetables, mushrooms, seaweed, fish and shellfish, beans, fruits, and sugar-sweetened beverages $(P<$ 0.05 , Table 2). There was a significant negative association between total vegetable intake and carbohydrate or grain intake $(P<0.05$, Table 2$)$.

Table 3 shows the standardized coefficients for the relationships between venous compliance and total vegetable intake, green/yellow vegetable intake, and white vegetable intake in multivariate linear regression analysis. In the unadjusted crude model, higher total vegetable intake and green/yellow vegetable intake were 
Table 1 Subject characteristics and Spearman's correlation coefficient $(r)$ values between total vegetable intake and these characteristics

\begin{tabular}{llll}
\hline & & $r$ & $P$ value \\
\hline Age, years & $20.2 \pm 1.1$ & 0.020 & 0.846 \\
Height, cm & $164.2 \pm 8.1$ & -0.205 & 0.047 \\
Weight, cm & $56.6 \pm 8.3$ & -0.211 & 0.041 \\
BMl & $20.9 \pm 2.3$ & -0.108 & 0.300 \\
Sex & & & \\
$\quad$ Male & $44(46.8)$ & 0.305 & 0.003 \\
$\quad$ Female & $50(53.2)$ & & \\
Maximal oxygen uptake, $\mathrm{mL} / \mathrm{min} / \mathrm{kg}$ & $38.4 \pm 7.0$ & -0.063 & 0.546 \\
Systolic blood pressure, $\mathrm{mmHg}$ & $123 \pm 12$ & -0.304 & 0.003 \\
Diastolic blood pressure, $\mathrm{mmHg}$ & $62 \pm 7$ & -0.135 & 0.194 \\
Heart rate, bpm & $65 \pm 12$ & -0.148 & 0.155 \\
Double product, mmHgxbpm & $7916 \pm 1461$ & -0.264 & 0.010 \\
\hline
\end{tabular}

Values are presented as the mean \pm standard deviation for continuous variables and as the number (\%) for categorical variables

Table 2 Dietary intake and Spearman's correlation coefficient ( $r$ ) values between total vegetable intake and dietary intake variables

\begin{tabular}{|c|c|c|c|}
\hline Energy intake, kcal/day & $1933 \pm 598$ & $\begin{array}{l}r \\
-0.045\end{array}$ & $\begin{array}{l}P \text { value } \\
0.667\end{array}$ \\
\hline \multicolumn{4}{|l|}{ Nutrient intake, g } \\
\hline Protein & $64.6 \pm 11.2$ & 0.450 & $<0.001$ \\
\hline Fat & $59.9 \pm 14.2$ & 0.442 & $<0.001$ \\
\hline Carbohydrate & $282.2 \pm 39.3$ & -0.407 & $<0.001$ \\
\hline \multicolumn{4}{|l|}{ Food group intake, $g$} \\
\hline Grains & $490.4 \pm 170.8$ & -0.462 & $<0.001$ \\
\hline Potato & $23.6 \pm 21.2$ & 0.361 & $<0.001$ \\
\hline Nuts and seeds & $1.0 \pm 1.6$ & 0.106 & 0.309 \\
\hline Green/yellow vegetables & $83.1 \pm 71.0$ & 0.815 & $<0.001$ \\
\hline White vegetables & $79.1 \pm 50.7$ & 0.747 & $<0.001$ \\
\hline Mushrooms & $7.4 \pm 9.2$ & 0.413 & $<0.001$ \\
\hline Seaweed & $10.3 \pm 12.2$ & 0.395 & $<0.001$ \\
\hline Fish and shellfish & $44.2 \pm 39.7$ & 0.420 & $<0.001$ \\
\hline Meats & $84.1 \pm 41.0$ & 0.160 & 0.124 \\
\hline Eggs & $34.0 \pm 28.4$ & -0.073 & 0.484 \\
\hline Beans & $56.0 \pm 50.1$ & 0.337 & 0.001 \\
\hline Milk and milk products & $134.4 \pm 170.4$ & 0.202 & 0.051 \\
\hline Fruit & $127.2 \pm 167.8$ & 0.248 & 0.016 \\
\hline Confectioneries & $73.7 \pm 45.9$ & 0.017 & 0.875 \\
\hline Sugar-sweetened beverages & $719.7 \pm 705.4$ & 0.218 & 0.035 \\
\hline Alcoholic beverages & $26.9 \pm 53.5$ & -0.117 & 0.261 \\
\hline
\end{tabular}

Values are presented as the mean \pm standard deviation for continuous variables. Data were adjusted for energy intake using the residual method
Table 3 Standardized coefficients $(\beta)$ for total, green/yellow, and white vegetable intakes and venous compliance in multivariate linear regression

\begin{tabular}{lll}
\hline & $\beta$ & $P$ value \\
\hline Total vegetables & \\
Crude & 0.260 & 0.011 \\
Model $1^{\dagger}$ & 0.245 & 0.020 \\
Model $2^{\ddagger}$ & 0.205 & 0.046 \\
Green/yellow vegetables & & \\
Crude & 0.351 & 0.001 \\
Model $1^{\dagger}$ & 0.339 & 0.001 \\
Model 2 ${ }^{\ddagger}$ & 0.306 & 0.003 \\
White vegetables & & \\
Crude & 0.013 & 0.902 \\
Model $1^{\dagger}$ & -0.008 & 0.941 \\
Model 2 & & 0.777 \\
\hline${ }^{\dagger}$ Adjusted by sex \\
${ }^{\ddagger}$ Adjusted by sex and maximal oxygen uptake
\end{tabular}

significantly associated with greater venous compliance (both $P<0.05$ ) but white vegetable intake was not. The significance of these results did not change in the multivariate linear regression models (1 and 2).

\section{Discussion}

The aim of this study was to investigate whether a relationship exists between vegetable consumption and venous compliance in young human adults. Simple linear regression analysis showed that higher total vegetable intake and green/yellow vegetable intake, but not white vegetable intake, were significantly associated with greater venous compliance. These relationships did not change in multivariate linear regression analysis, which was adjusted by sex and $\mathrm{V}_{2 \max }$. These findings suggest that higher consumption of vegetables, especially green/ yellow vegetables, might increase venous compliance in young healthy adults.

We found a significant association between higher vegetable consumption and greater calf venous compliance (Table 3). To our knowledge, this is the first study to investigate the relationship between vegetable consumption and venous compliance. Vegetables contain abundant nutrients and phytochemicals. Dietary fiber, magnesium, potassium, vitamin $\mathrm{K}$, vitamin $\mathrm{C}$, flavonoids, carotenoids, nitrates, and organosulfur compounds could be beneficial for cardiovascular health [18] via a number of mechanisms, including antioxidant and anti-inflammatory activity, increased production of $\mathrm{NO}$, and changes in gene expression and signaling pathways [20-23, 47]. It is possible that control of venous compliance is influenced by a combination of these mechanisms. However, exactly 
which of these contributes the most to venous compliance has yet to be investigated.

Another finding in this study was a significant positive correlation of greater venous compliance with intake of green/yellow vegetables but not white vegetables (Table 3). As mentioned earlier, vegetables contain abundant nutrients and phytochemicals, and many recent studies have reported that nitrates, found predominantly in green leafy vegetables, beetroot, and radish, could improve endothelial function [25-32] and arterial stiffness [29, 31-33] in humans. Vegetable-derived nitrates are thought to increase NO via the enterosalivary nitrate-nitrite-NO pathway. NO has many physiological effects, including relaxation of vascular smooth muscle, elevation of regional blood flow, and inhibition of adhesion of platelets and leukocytes [48], which may cohesively improve endothelial function and prevent arterial stiffness. Venous tone is also regulated by NO [34-38]. Therefore, a possible reason for our finding of an association between green/yellow vegetable intake and calf venous compliance may be the nitrate content of these foods.

Some previous studies have been reported that there are "responders" and "non-responders" to the dietary nitrate supplementation $[49,50]$. In the present study, the possibility of individual differences for the effect of green/yellow vegetable intake on venous compliance could not be excluded. Although we have no certain idea, the degree of nitric oxide synthase activity might be considered such as the one of reason for individual variation because nitric oxide synthase has been increased by physical activity [51-53]. Indeed, the variability of physical fitness level between subjects in this study was large (e.g., $\mathrm{VO}_{2 \text { max }}: 26.3$ $\sim 54.8 \mathrm{~mL} / \mathrm{min} / \mathrm{kg}$ ). Thus, as physical activity was higher, the production of $\mathrm{NO}$ might be greater, so that venous compliance might be also higher even though the green/ yellow vegetable consumption was equal.

Our results could have physiological and clinical significance. Changes in venous structure and function have been described in hypertension $[6,8,54-56]$. For example, both venous compliance and capacitance were found to be decreased in hypertensive subjects [6, 54-56]. Furthermore, in our study, calf venous compliance tended to correlate negatively with SBP (males: $r=-0.294, P=0.052$; females: $r=-0.239, P=0.095$ ) and DP (males: $r=$ $-0.275, P=0.092$; females: $r=-0.265, P=0.063)$ in healthy young subjects. Because venous vascular health is likely to deteriorate with age, maintaining high venous compliance from young adulthood could help to prevent age-related hypertension. Our finding of a possible relationship between consumption of green/yellow vegetables and calf venous compliance in healthy young subjects may pave the way for dietary approaches to prevent or attenuate chronic diseases such as hypertension. Further studies are needed to identify the nutrients and/or phytochemicals in these vegetables that modify venous structure and function.

This study has several limitations. First, the crosssectional design and the small number of young subjects might have introduced a degree of sampling bias. Therefore, our results cannot be generalized. Second, dietary intake was self-reported. However, the questionnaire used in our research has been validated in previous studies $[40,42]$, and so we consider our findings credible. Third, this study did not consider the potential effects of the menstrual cycle in female subjects. However, given the evidence that venous compliance at rest does not vary with the menstrual cycle [57], menstruation could be expected to have had little effect on venous compliance in our study. Finally, although we adjusted sex and maximal oxygen uptake in the multivariate linear regression, there could still be potential residual confoundings such as the use of mouthwash and the diets which could affect the venous compliance. However, since we did not control the diet and the mouthwash at least 3 days before the venous compliance assessment, the acute effects of these factors on venous compliance, if any, cannot be excluded completely in this study. Thus, further study would be needed to investigate the effect of vegetable consumption on venous compliance under the experimental condition that the diet and the mouthwash are controlled.

\section{Conclusions}

This study investigated the relationship between vegetable consumption and calf venous compliance in young healthy adults. Our findings suggest that a higher intake of vegetables, especially of the green/yellow vegetables, might increase the venous compliance in this population.

\section{Abbreviations \\ DBP: Diastolic blood pressure; DHQ: Diet history questionnaire; DP: Double product; HR: Heart rate; NO: Nitric oxide; SBP: Systolic blood pressure; $V$ \\ $\mathrm{O}_{2 \text { max }}$ maximal oxygen uptake}

\section{Acknowledgements \\ We would like to express our gratitude to the subjects who volunteered to participate in this study.}

\section{Authors' contributions}

A.O. conceived and designed the experiments; A.O., Y.I., and K.M. performed the experiments; A.O., Y.I., K.M., and T.Y. analyzed and interpreted the data; A.O. wrote the paper. All authors read and approved the final manuscript.

\section{Funding}

This research was supported by a Grant-in-Aid for Scientific Research (C) (18 K10974) from the Japan Society for the Promotion of Science.

Availability of data and materials

All data generated or analyzed during this study are included in this published article. 


\section{Ethics approval and consent to participate}

This study was approved by the Human Ethics Committee of Toyo University and was conducted in accordance with the Declaration of Helsinki except for registration in a database. All subjects provided written and verbal informed consent after receiving a detailed explanation of the purpose, procedures, and risks of the study.

\section{Consent for publication}

Not applicable.

\section{Competing interests}

The authors declare that they have no competing interests.

\section{Author details}

${ }^{1}$ Faculty of Food and Nutritional Sciences, Toyo University, 1-1-1 Izumino, Itakura-machi, Ora-gun, Gunma 374-0193, Japan. ${ }^{2}$ Graduate School of Food and Nutritional Sciences, Toyo University, Gunma 374-0193, Japan.

Received: 19 May 2020 Accepted: 2 August 2020

Published online: 12 August 2020

\section{References}

1. Hernandez JP, Franke WD. Age- and fitness-related differences in limb venous compliance do not affect tolerance to maximal lower body negative pressure in men and women. J Appl Physiol. 2004;97:925-9.

2. Monahan KD, Dinenno FA, Seals DR, Halliwill JR. Smaller age-associated reductions in leg venous compliance in endurance exercise-trained men. Am J Physiol Heart Circ Physiol. 2001;281:H1267-73.

3. Olsen H, Lanne T. Reduced venous compliance in lower limbs of aging humans and its importance for capacitance function. Am J Phys. 1998;275: H878-86.

4. Young CN, Stillabower ME, DiSabatino A, Farquhar WB. Venous smooth muscle tone and responsiveness in older adults. J Appl Physiol. 2006;101: 1362-7.

5. Rothe CF. Venous system: physiology of the capacitance vessels. In: Shephard JT, Abbound FM, editors. Handbook of Physiology: The cardiovascular System III. Baltimore: Waverly Press; 1983.

6. London GM, Safar ME, Simon AC, Alexandre JM, Levenson JA, Weiss YA Total effective compliance, cardiac output and fluid volumes in essentia hypertension. Circulation. 1978;57:995-1000.

7. Takeshita A, Mark AL. Decreased venous distensibility in borderline hypertension. Hypertension. 1979;1:202-6.

8. Fink GD, Johnson RJ, Galligan JJ. Mechanisms of increased venous smooth muscle tone in desoxycorticosterone acetate-salt hypertension. Hypertension. 2000;35:464-9.

9. Simon G. Altered venous function in hypertensive rats. Circ Res. 1976;38: $412-8$

10. Simon G, Pamnani MB, Dunkel JF, Overbeck HW. Mesenteric hemodynamics in early experimental renal hypertension in dogs. Circ Res. 1975;36:791-8.

11. lida H, Nakajima T, Kurano M, Yasuda T, Sakamaki M, Sato Y, Yamasoba T, Abe T. Effects of walking with blood flow restriction on limb venous compliance in elderly subjects. Clin Physiol Funct Imaging. 2011;31:472-6.

12. Oue A, Saito $M$, limura $Y$. Effect of short-term endurance training on venous compliance in the calf and forearm differs between continuous and interval exercise in humans. Phys Rep. 2019. https://doi.org/10.14814/phy2.14211.

13. Scholten RR, Hopman MT, Lotgering FK, Spaanderman ME. Aerobic exercise training in formerly preeclamptic women: effects on venous reserve. Hypertension. 2015;66:1058-65.

14. Aune D, Giovannucci E, Boffetta P, Fadnes LT, Keum N, Norat T, Greenwood DC, Riboli E, Vatten LJ, Tonstad S. Fruit and vegetable intake and the risk of cardiovascular disease, total cancer and all-cause mortality-a systematic review and dose-response meta-analysis of prospective studies. Int J Epidemiol. 2017:46:1029-56.

15. He FJ, Nowson CA, Lucas M, MacGregor GA. Increased consumption of fruit and vegetables is related to a reduced risk of coronary heart disease: metaanalysis of cohort studies. J Hum Hypertens. 2007;21:717-28.

16. Woodside JV, Young IS, McKinley MC. Fruit and vegetable intake and risk of cardiovascular disease. Proc Nutr Soc. 2013;72:399-406.

17. McCall DO, McGartland CP, McKinley MC, Patterson CC, Sharpe P, McCance DR, Young IS, Woodside JV. Dietary intake of fruits and vegetables improves microvascular function in hypertensive subjects in a dose-dependent manner. Circulation. 2009:119:2153-60.

18. Blekkenhorst LC, Sim M, Bondonno CP, Bondonno NP, Ward NC, Prince RL, Devine A, Lewis JR, Hodgson JM. Cardiovascular health benefits of specific vegetable types: a narrative review. Nutrients. 2018. https://doi.org/10.3390/ nu10050595.

19. Liu RH. Health-promoting components of fruits and vegetables in the diet. Adv Nutr. 2013:4:3845-92S.

20. Bondonno CP, Blekkenhorst LC, Liu AH, Bondonno NP, Ward NC, Croft KD, Hodgson JM. Vegetable-derived bioactive nitrate and cardiovascular health. Mol Asp Med. 2018;61:83-91.

21. Boyle SP, Dobson VL, Duthie SJ, Kyle JA, Collins AR. Absorption and DNA protective effects of flavonoid glycosides from an onion meal. Eur J Nutr. 2000;39:213-23.

22. Collins AR, Harrington V, Drew J, Melvin R. Nutritional modulation of DNA repair in a human intervention study. Carcinogenesis. 2003;24:511-5.

23. Root MM, McGinn MC, Nieman DC, Henson DA, Heinz SA, Shanely RA, Knab AM, Jin F. Combined fruit and vegetable intake is correlated with improved inflammatory and oxidant status from a cross-sectional study in a community setting. Nutrients. 2012;4:29-41.

24. Blekkenhorst LC, Prince RL, Ward NC, Croft KD, Lewis JR, Devine A, Shinde S, Woodman RJ, Hodgson JM, Bondonno CP. Development of a reference database for assessing dietary nitrate in vegetables. Mol Nutr Food Res. 2017. https://doi.org/10.1002/mnfr.201600982.

25. Bakker E, Engan H, Patrician A, Schagatay E, Karlsen T, Wisløff U, Gaustad SE. Acute dietary nitrate supplementation improves arterial endothelial function at high altitude: a double-blinded randomized controlled cross over study. Nitric Oxide. 2015:50:58-64.

26. Bondonno CP, Yang X, Croft KD, Considine MJ, Ward NC, Rich L, Puddey IB, Swinny E, Mubarak A, Hodgson JM. Flavonoid-rich apples and nitrate-rich spinach augment nitric oxide status and improve endothelial function in healthy men and women: a randomized controlled trial. Free Radic Biol Med. 2012:52:95-102.

27. Heiss C, Meyer C, Totzeck M, Hendgen-Cotta UB, Heinen Y, Luedike P, Keymel S, Ayoub N, Lundberg JO, Weitzberg E, Kelm M, Rassaf T. Dietary inorganic nitrate mobilizes circulating angiogenic cells. Free Radic Biol Med. 2012:52:1767-72.

28. Joris PJ, Mensink RP. Beetroot juice improves in overweight and slightly obese men postprandial endothelial function after consumption of a mixed meal. Atherosclerosis. 2013;231:78-83.

29. Kapil V, Khambata RS, Robertson A, Caulfield MJ, Ahluwalia A. Dietary nitrate provides sustained blood pressure lowering in hypertensive patients: a randomized, phase 2, double-blind, placebo-controlled study. Hypertension. 2015;65:320-7.

30. Rodriguez-Mateos A, Hezel M, Aydin H, Kelm M, Lundberg JO, Weitzberg E, Spencer JP, Heiss C. Interactions between cocoa flavanols and inorganic nitrate: additive effects on endothelial function at achievable dietary amounts. Free Radic Biol Med. 2015:80:121-8.

31. Rammos C, Hendgen-Cotta UB, Sobierajski J, Bernard A, Kelm M, Rassaf T. Dietary nitrate reverses vascular dysfunction in older adults with moderately increased cardiovascular risk. J Am Coll Cardiol. 2014;63:1584-5.

32. Velmurugan S, Gan JM, Rathod KS, Khambata RS, Ghosh SM, Hartley A, Van Eijl S, Sagi-Kiss V, Chowdhury TA, Curtis M, Kuhnle GG, Wade WG, Ahluwalia A. Dietary nitrate improves vascular function in patients with hypercholesterolemia: a randomized, double-blind, placebo-controlled study. Am J Clin Nutr. 2016;103:25-38.

33. Bahra M, Kapil V, Pearl V, Ghosh S, Ahluwalia A. Inorganic nitrate ingestion improves vascular compliance but does not alter flow-mediated dilatation in healthy volunteers. Nitric Oxide. 2012;26:197-202.

34. Blackman DJ, Morris-Thurgood JA, Atherton JJ, Ellis GR, Anderson RA, Cockcroft JR, Frenneaux MP. Endothelium-derived nitric oxide contributes to the regulation of venous tone in humans. Circulation. 2000;101:165-70.

35. Hamilton CA, Berg G, Mcintyre M, Mcphaden AR, Reid JL, Dominiczak AF. Effects of nitric oxide and superoxide on relaxation in human artery and vein. Atherosclerosis. 1997:133:77-86.

36. Lüscher TF, Diederich D, Siebenmann R, Lehmann K, Stulz P, von Segesser L, Yang ZH, Turina M, Grädel E, Weber E, Bühler FR. Difference between endothelium-dependent relaxation in arterial and in venous coronary bypass grafts. N Engl J Med. 1988;319:462-7.

37. Vallance $P$, Collier J, Moncada S. Nitric oxide synthesised from L-arginine mediates endothelium dependent dilatation in human veins in vivo. Cardiovasc Res. 1989;23:1053-7. 
38. Yang ZH, von Segesser L, Bauer E, Stulz P, Turina M, Lüscher TF. Different activation of the endothelial L-arginine and cyclooxygenase pathway in the human internal mammary artery and saphenous vein. Circ Res. 1991;68:52-60.

39. Kobayashi S, Honda S, Murakami K, Sasaki S, Okubo H, Hirota N, Notsu A, Fukui M, Date C. Both comprehensive and brief self-administered diet history questionnaires satisfactorily rank nutrient intakes in Japanese adults. J Epidemiol. 2012;22:151-9.

40. Kobayashi S, Murakami K, Sasaki S, Okubo H, Hirota N, Notsu A, Fukui M, Date C. Comparison of relative validity of food group intakes estimated by comprehensive and brief-type self-administered diet history questionnaires against 16 d dietary records in Japanese adults. Public Health Nutr. 2011;14: 1200-11.

41. Willett W, Stampfer MJ. Total energy intake: implications for epidemiologic analyses. Am J Epidemiol. 1986;124:17-27.

42. Okubo H, Sasaki S, Rafamantanantsoa HH, Ishikawa-Takata K, Okazaki H, Tabata I. Validation of self-reported energy intake by a self-administered diet history questionnaire using the doubly labeled water method in 140 Japanese adults. Eur J Clin Nutr. 2008;62:1343-50.

43. Halliwill JR, Minson CT, Joyner MJ. Measurement of limb venous compliance in humans: technical considerations and physiological findings. J Appl Physiol. 1999;87:1555-63.

44. Skoog J, Zachrisson H, Lindenberger M, Ekman M, Ewerman L, Länne T. Calf venous compliance measured by venous occlusion plethysmography: methodological aspects. Eur J Appl Physiol. 2015;115:245-56.

45. Freeman R, Lirofonis V, Farquhar WB, Risk M. Limb venous compliance in patients with idiopathic orthostatic intolerance and postural tachycardia. J Appl Physiol. 2002;93:636-44.

46. Willett W. Nutritional epidemiology. 3rd ed. New York: Oxford University Press; 2003

47. Tang GY, Meng X, Li Y, Zhao CN, Liu Q, Li HB. Effects of vegetables on cardiovascular diseases and related mechanisms. Nutrients. 2017;9. https:// doi.org/10.3390/nu9080857.

48. Förstermann U, Münzel T. Endothelial nitric oxide synthase in vascular disease: from marvel to menace. Circulation. 2006;113:1708-14.

49. Wilkerson DP, Hayward GM, Bailey SJ, Vanhatalo A, Blackwell JR, Jones AM. Influence of acute dietary nitrate supplementation on 50 mile time trial performance in well-trained cyclists. Eur J Appl Physiol. 2012;112:4127-34.

50. Wylie LJ, Kelly J, Bailey SJ, Blackwell JR, Skiba PF, Winyard PG, Jeukendrup AE, Vanhatalo A, Jones AM. Beetroot juice and exercise: pharmacodynamic and dose-response relationships. J Appl Physiol. 2013;115:325-36.

51. McAllister RM, Laughlin MH. Vascular nitric oxide: effects of physical activity, importance for health. Essays Biochem. 2006;42:119-31.

52. McConell GK, Bradley SJ, Stephens TJ, Canny BJ, Kingwell BA, Lee-Young RS. Skeletal muscle nNOS mu protein content is increased by exercise training in humans. Am J Phys Regul Integr Comp Phys. 2007;293:R821-8.

53. Nyberg M, Blackwell JR, Damsgaard R, Jones AM, Hellsten Y, Mortensen SP. Lifelong physical activity prevents an age-related reduction in arterial and skeletal muscle nitric oxide bioavailability in humans. J Physiol. 2012;590: 5361-70.

54. Delaney EP, Young CN, Disabatino A, Stillabower ME, Farquhar WB. Limb venous tone and responsiveness in hypertensive humans. J Appl Physiol. 2008;105:894-901.

55. Fitzpatrick MA, Hinderliter AL, Egan BM, Julius S. Decreased venous distensibility and reduced renin responsiveness in hypertension. Hypertension. 1986;8:II36-43.

56. Safar ME, London GM. Arterial and venous compliance in sustained essential hypertension. Hypertension. 1987;10:133-9.

57. Meendering JR, Torgrimson BN, Houghton BL, Halliwill JR, Minson CT. Effects of menstrual cycle and oral contraceptive use on calf venous compliance. Am J Physiol Heart Circ Physiol. 2005;288:H103-10.

\section{Publisher's Note}

Springer Nature remains neutral with regard to jurisdictional claims in published maps and institutional affiliations.

Ready to submit your research? Choose BMC and benefit from:

- fast, convenient online submission

- thorough peer review by experienced researchers in your field

- rapid publication on acceptance

- support for research data, including large and complex data types

- gold Open Access which fosters wider collaboration and increased citations

- maximum visibility for your research: over $100 \mathrm{M}$ website views per year

At BMC, research is always in progress.

Learn more biomedcentral.com/submissions 